\title{
Flowering phenology in a species-rich temperate grassland is sensitive to warming but not elevated $\mathrm{CO}_{2}$
}

\author{
Mark J. Hovenden ${ }^{1}$, Karen E. Wills ${ }^{1}$, Jacqueline K. Vander Schoor ${ }^{1}$, Amity L. Williams ${ }^{1}$ and Paul C. D. Newton ${ }^{2}$ \\ ${ }^{1}$ School of Plant Science, University of Tasmania, Hobart, Tasmania, Australia; ${ }^{2}$ Land \& Environmental Management, AgResearch, Palmerston North, \\ New Zealand
}

\section{Summary}

Author for correspondence:

Mark J. Hovenden

Tel: +61362267874

Fax: +61362262698

Email: Mark.Hovenden@utas.edu.au

Received: 9 December 2007

Accepted: 25 January 2008
- Flowering is a critical stage in plant life cycles, and changes might alter processes at the species, community and ecosystem levels. Therefore, likely flowering-time responses to global change drivers are needed for predictions of global change impacts on natural and managed ecosystems.

- Here, the impact of elevated atmospheric $\mathrm{CO}_{2}$ concentration $\left(\left[\mathrm{CO}_{2}\right]\right)(550 \mu \mathrm{mol}$ $\left.\mathrm{mol}^{-1}\right)$ and warming $\left(+2^{\circ} \mathrm{C}\right)$ is reported on flowering times in a native, species-rich, temperate grassland in Tasmania, Australia in both 2004 and 2005.

- Elevated $\left[\mathrm{CO}_{2}\right]$ did not affect average time of first flowering in either year, only affecting three out of 23 species. Warming reduced time to first flowering by an average of $19.1 \mathrm{~d}$ in 2004 , acting on most species, but did not significantly alter flowering time in 2005, which might be related to the timing of rainfall. Elevated $\left[\mathrm{CO}_{2}\right]$ and warming treatments did not interact on flowering time.

- These results show elevated $\left[\mathrm{CO}_{2}\right]$ did not alter average flowering time or duration in this grassland; neither did it alter the response to warming. Therefore, flowering phenology appears insensitive to increasing $\left[\mathrm{CO}_{2}\right]$ in this ecosystem, although the response to warming varies between years but can be strong.

Key words: climate change, elevated $\mathrm{CO}_{2}$, flowering, free-air $\mathrm{CO}_{2}$ enrichment (FACE), global warming, grassland, phenology.

New Phytologist (2008) doi: 10.1111/j.1469-8137.2008.02419.x

(C) The Authors (2008). Journal compilation (c) New Phytologist (2008)

\section{Introduction}

There is now sufficient evidence to be certain that the timing of recurring, or phenological, biological events is shifting in response to global changes (Penuelas \& Filella, 2001; Sparks \& Menzel, 2002; Beaubien \& Hall-Beyer, 2003; Menzel, 2003; Badeck et al., 2004; Penuelas et al., 2004; Primack et al., 2004; Walther, 2004; Menzel et al., 2006). This evidence comes from both experimental climate-manipulation studies (Price \& Waser, 1998; Saavedra et al., 2003; Cleland et al., 2006; Sherry et al., 2007) and long-term observations (Myneni et al., 1997; Ahas et al., 2002; Fitter \& Fitter, 2002; Penuelas et al., 2002; Walther et al., 2002; Beaubien \& Hall-Beyer, 2003; Scheifinger et al., 2003; Stefanescu et al., 2003; Badeck et al., 2004; Primack et al., 2004), as well as from sophisticated, combined observational-modeling studies
(Osborne et al., 2000; Badeck et al., 2004; Dose \& Menzel, 2006; Estrella et al., 2006; Schleip et al., 2006). It is clear from the results of these studies that rising temperatures have already accelerated many spring phenomena including bud-break of deciduous trees (Badeck et al., 2004), ecosystem primary productivity increase (Keeling et al., 1996; Randerson et al., 1999; Zhou et al., 2001) and flowering of alpine and arctic plants (Price \& Waser, 1998; Arft et al., 1999; Suzuki \& Kudo, 2000; De Valpine \& Harte, 2001; Dunne et al., 2003) and crops (Estrella et al., 2007). However, current global changes involve more than just an increasing mean surface temperature. Especially important in this regard, particularly when considering plant phenological patterns, is the increasing atmospheric concentration of $\mathrm{CO}_{2}\left(\left[\mathrm{CO}_{2}\right]\right)$ which has the potential to alter the strength and timing of plant biomass allocation patterns, including flower production (Badeck 
et al., 2004). Because temperature and $\left[\mathrm{CO}_{2}\right]$ are linked in nature, it is difficult to disentangle their relative effects on plant phenology, especially as other factors such as rainfall can also affect phenology (Guak et al., 1998; Norby et al., 2003; Penuelas et al., 2004). Therefore, experimental manipulations are particularly valuable in determining the causative factors of shifting phenological events (Badeck et al., 2004; Cleland et al., 2006). Despite the strength of a multifactor experimental approach, relatively few reports exist of phenological responses to more than one global change factor (Guak et al., 1998; Norby et al., 2003; Cleland et al., 2006). There are also few reports, either observational or experimental, of phenological patterns from the southern hemisphere. This is of concern since temperate latitudes in the southern hemisphere are different from similar latitudes in the northern hemisphere, mostly as a result of the lack of large landmasses at temperate latitudes in the southern hemisphere. Thus, southern temperate ecosystems tend to have milder winters and, apart from coastal areas, are generally drier than similar latitudes in the northern hemisphere (Reid et al., 1999).

Timing of flowering is a crucial aspect of a plant's life cycle. Pollination success, particularly in animal-pollinated species, depends upon the timing of flower opening. Changes in flowering commencement are also likely to lead to changes in fruit ripening and seed dispersal, with impacts not only on a plant and its competitors, but on many other trophic levels. Thus, changes in flowering times are likely to have major ramifications for ecosystem function (Arft et al., 1999; Walther et al., 2002; Badeck et al., 2004; Cleland et al., 2007).

Here, we investigate the effects of experimental warming and elevated $\mathrm{CO}_{2}$, both singly and interactively, on flowering phenology of a range of native and exotic species of various growth forms in an Australian temperate grassland over 2 yr.

\section{Materials and Methods}

\section{Study site and experimental design}

Flowering was monitored throughout the year from March (autumn) 2004 until March 2007 in the TasFACE climate change impacts experiment at Pontville in southeastern Tasmania, Australia $\left(42^{\circ} 42^{\prime} \mathrm{S} 147^{\circ} 16^{\prime} \mathrm{E}, 40 \mathrm{~m}\right.$ above sea-level (asl)). This experiment exposed a species-rich temperate grassland to both pure- $\mathrm{CO}_{2}$ free-air $\mathrm{CO}_{2}$ enrichment (FACE) and infrared warming. Treatment commenced in February 2002. Elevated $\mathrm{CO}_{2}\left(550 \mu \mathrm{mol} \mathrm{mol}^{-1}\right)$ and warming $\left(+2^{\circ} \mathrm{C}\right)$ were applied in $1.5-\mathrm{m}$ diameter circular plots with three replicate plots of each $\mathrm{CO}_{2} \times$ warming combination, giving 12 experimental plots in total. The $\left[\mathrm{CO}_{2}\right]$ in the elevated $\mathrm{CO}_{2}$ plots was controlled by pure- $\mathrm{CO}_{2}$ fumigation free-air $\mathrm{CO}_{2}$ enrichment (FACE, Miglietta et al., 2001), operating from sunrise to sunset. The system uses proportional control of $\left[\mathrm{CO}_{2}\right]$ in the centre of each plot by manipulating $\mathrm{CO}_{2}$ supply with electropneumatic flow control valves (CKD USA, Rolling Meadows, IL, USA). Valves are controlled via a microprocessor-based control system running a proportional integration device algorithm (Hendrey et al., 1993, 1999). The control of $\mathrm{CO}_{2}$ is excellent, with the central $\left[\mathrm{CO}_{2}\right]$ in all plots being within $10 \%$ of the set-point over $85 \%$ of the time. Full details of the experimental design and system performance were provided in Hovenden et al. (2006).

Warming of $2.0^{\circ} \mathrm{C}$ was achieved by using overhead ceramic infrared heat lamps (Salamanda ESE250 $240 \mathrm{~V} 250 \mathrm{~W}$ Emerson Solid Ceramic Infrared Emitter; Delta-T, Melbourne, Australia) that operated continuously, supplying $140 \mathrm{~W} \mathrm{~m}^{-2}$ of infrared radiation. The lamps produced no visible radiation and on average during the growing season (Mar-Dec) elevated canopy temperature by $1.98 \pm 0.05^{\circ} \mathrm{C}$ and soil temperature at $5 \mathrm{~mm}$ by $0.82 \pm 0.04^{\circ} \mathrm{C}$. Night-time warming was more pronounced than daytime warming because of the influence of direct solar radiation. Thus, canopy temperature was elevated by an average of $1.54 \pm 0.20^{\circ} \mathrm{C}$ during the day and $2.61 \pm 0.14^{\circ} \mathrm{C}$ during the night. Similarly, soil warming at $5 \mathrm{~mm}$ depth was $1.79 \pm 0.10^{\circ} \mathrm{C}$ during the night but only $0.14 \pm 0.013^{\circ} \mathrm{C}$ during the day. Warming and elevated $\mathrm{CO}_{2}$ treatments interacted to affect soil moisture content with the mean soil water potential for the period March 2004 until March 2007 being $-113 \pm 19 \mathrm{kPa}$ in unwarmed control plots, $-112 \pm 18 \mathrm{kPa}$ in warmed control plots, $-91 \pm 13 \mathrm{kPa}$ in unwarmed elevated $\mathrm{CO}_{2}$ plots and $-126 \pm 12 \mathrm{kPa}$ in warmed elevated $\mathrm{CO}_{2}$ plots. Differences in soil moisture were most pronounced during periods of intermediate water availability and disappeared under wet or dry conditions.

The vegetation at the site is dominated by the $\mathrm{C}_{4}$ perennial grass Themeda triandra, which is the only $\mathrm{C}_{4}$ species found at the site. The $\mathrm{C}_{3}$ perennial grasses Austrodanthonia spp. and Austrostipa spp. are also abundant (nomenclature follows Buchanan, 1999). Exotic annual grasses include Vulpia myuros, Briza minor and Aira praecox. Abundant herbaceous dicots include the native species Calocephalus citreus, Leptorhynchos squamatus and Solenogyne dominii and the exotic species Hypochaeris glabra, Hypochaeris radicata and Leontodon taraxacoides. Nitrogen-fixing forbs, which include Trifolium subterraneum and Trifolium striatum, are rare and form an extremely small fraction of the biomass $(<0.05 \%)$. The grassland community also contains the woody species Hibbertia hirsuta and Bossiaea prostrata, which is a nitrogen-fixing species but again forms a small proportion of the biomass $(<1 \%)$. There is evidence that species dominance at the site is changing as a result of the experimental manipulations (Williams et al., 2007). The soil at the site is a black vertisol formed of basaltic clay, $\mathrm{pH}$ c. 6.5, with low total nitrogen (N) (approx. 0.2\%) and extractable phosphorus (P) (approx. $20 \mathrm{mg} \mathrm{kg}^{-1}$ ). The site has a mean annual temperature of $11.6^{\circ} \mathrm{C}$, a mean annual rainfall of $560 \mathrm{~mm}$ and experiences substantial summer drought between December and March/April. 


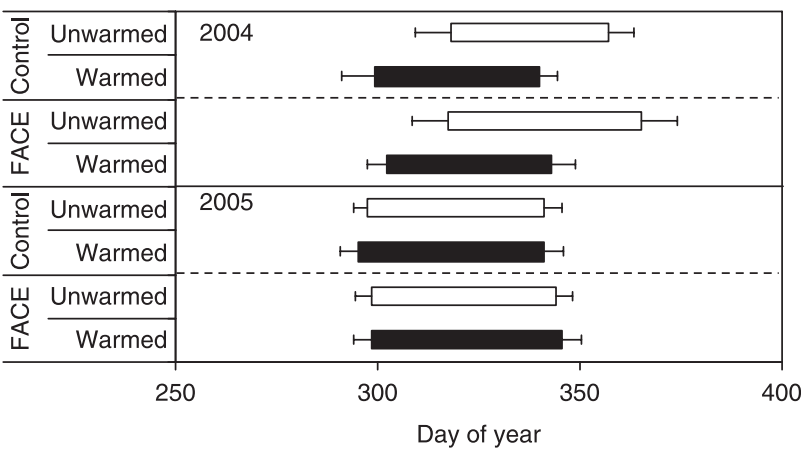

Fig. 1 Average flowering times in unwarmed (open bars) and warmed (closed bars) plots in 2004 and 2005 in the Tasmanian free-air $\mathrm{CO}_{2}$ enrichment experiment (TasFACE) experiment exposed to both free-air $\mathrm{CO}_{2}$ enrichment (FACE) and control atmospheric $\mathrm{CO}_{2}$ concentration $\left(\left[\mathrm{CO}_{2}\right]\right)$. Bars indicate flowering duration from mean flowering commencement to mean flowering conclusion, error bars indicate \pm SE.

Table 1 Results of ANOVA showing effects of elevated $\mathrm{CO}_{2}$, warming, year and all interactions on flowering commencement and conclusion times and flowering duration in the Tasmanian free-air $\mathrm{CO}_{2}$ enrichment experiment (TasFACE) during 2004 and 2005

\begin{tabular}{|c|c|c|c|}
\hline \multirow[b]{2}{*}{ Effect } & \multicolumn{3}{|l|}{ Variable } \\
\hline & First flowering & Last flowering & Duration \\
\hline $\mathrm{CO}_{2}$ & 0.42 & 0.80 & 0.66 \\
\hline Warming (W) & $<0.0001$ & $<0.0001$ & 0.87 \\
\hline $\mathrm{CO}_{2} \times \mathrm{W}$ & 0.40 & 0.19 & 0.63 \\
\hline Year $(Y)$ & 0.0002 & 0.03 & $<0.0001$ \\
\hline $\mathrm{CO}_{2} \times \mathrm{Y}$ & 0.55 & 0.51 & 0.92 \\
\hline$W \times Y$ & $<0.0001$ & 0.007 & 0.18 \\
\hline $\mathrm{C} \times \mathrm{W} \times \mathrm{Y}$ & 0.78 & 0.87 & 0.94 \\
\hline
\end{tabular}

Values shown are probabilities associated with the $F$ ratio; significant effects $(P<0.05)$ are shown in bold type.

\section{Climate measurements}

All climate measurements were made using a Campbell Scientific automatic weather station with hourly measurements logged to a CRX-10 data logger (Campbell Scientific Australia, Townsville, Australia). Degree-days were calculated using hourly air temperature data and were summed from 01:00 h on 1 July in each year.

\section{Flowering measurements}

Flowering of all species in each plot was recorded from March 2004 until March 2006 and thus data cover two complete flowering seasons. During this period, the number of flowering individuals and the number of inflorescences produced was recorded each week during periods of low flower production and two to three times per week during peak flowering periods (Sept-Dec). Flowering was defined as the presence of open flowers or exposed stamens and/or styles for grasses. From these observations, the time to first flowering and the time of last flowering were calculated separately for each species in each plot as the number of days after 1 January in each year. As flowering times of some species extend into the subsequent calendar year, the day for last flowering for these species was calculated as the number of days from 1 January of the previous year. The duration of flowering was calculated as the difference between last flowering and first flowering for each species in each plot.

\section{Data analyses}

Data were analysed by mixed model repeated measures analysis of variance (ANOVA) using general linear model procedures (PROC GLM) in the SAS statistical software package, version 9.1 (SAS Institute Inc., 2003). The model used had $\mathrm{CO}_{2}$ and warming as fixed, orthogonal factors with repeated years. Warming and $\mathrm{CO}_{2}$ effects were also analysed by repeated measures ANOVA separately for each species.

\section{Results}

\section{Flowering commencement}

Flowering commencement date averaged across all species was not affected by $\mathrm{CO}_{2}$ concentration (Fig. 1; Table 1); neither was there any significant interaction between $\mathrm{CO}_{2}$ and any of the other factors (Table 1). This lack of any $\mathrm{CO}_{2}$ effect was consistent across years, as demonstrated by the nonsignificant $\mathrm{CO}_{2} \times$ year interaction (Table 1). In 2004, mean first flowering day averaged across all species was $308.9 \pm 3.8$ (mean \pm SE throughout) (Fig. 1). Flowering was slightly earlier in 2005 $(P<0.0002$; Fig. 1), with first flowers appearing, on average, on day $297.5 \pm 2.0$.

In close agreement with the average response, there were few significant effects at the species level, with first flowering date being significantly affected by elevated $\mathrm{CO}_{2}$ in only two species in 2004 and three in 2005 (see the Supplementary Material, Table S1). Furthermore, the responses of these few species to elevated $\mathrm{CO}_{2}$ were inconsistent across years (Fig. 2). Indeed, time to first flowering was significantly affected by elevated $\mathrm{CO}_{2}$ in both years in both $L$. squamatus and V. myuros, but the direction of the effect differed between years. In $V$. myuros, elevated $\mathrm{CO}_{2}$ accelerated flowering in 2004 $(P<0.05)$ but delayed flowering in $2005(P<0.04$; Fig. 2$)$, whereas the situation was reversed for $L$. squamatus $(P<0.02$ both years; Fig. 2). Flowering of $H$. hirsuta was accelerated in 2005 by $24.5 \mathrm{~d}(P<0.01$, Fig. 2$)$, but was unaffected by $\mathrm{CO}_{2}$ concentration in $2004(P<0.21$; Fig. 2$)$.

In agreement with many previous reports, the time to first flowering was substantially affected by both warming (Fig. 1; Table 1$)$ and a warming $\times$ year interaction (Fig. 1; Table 1 ). 


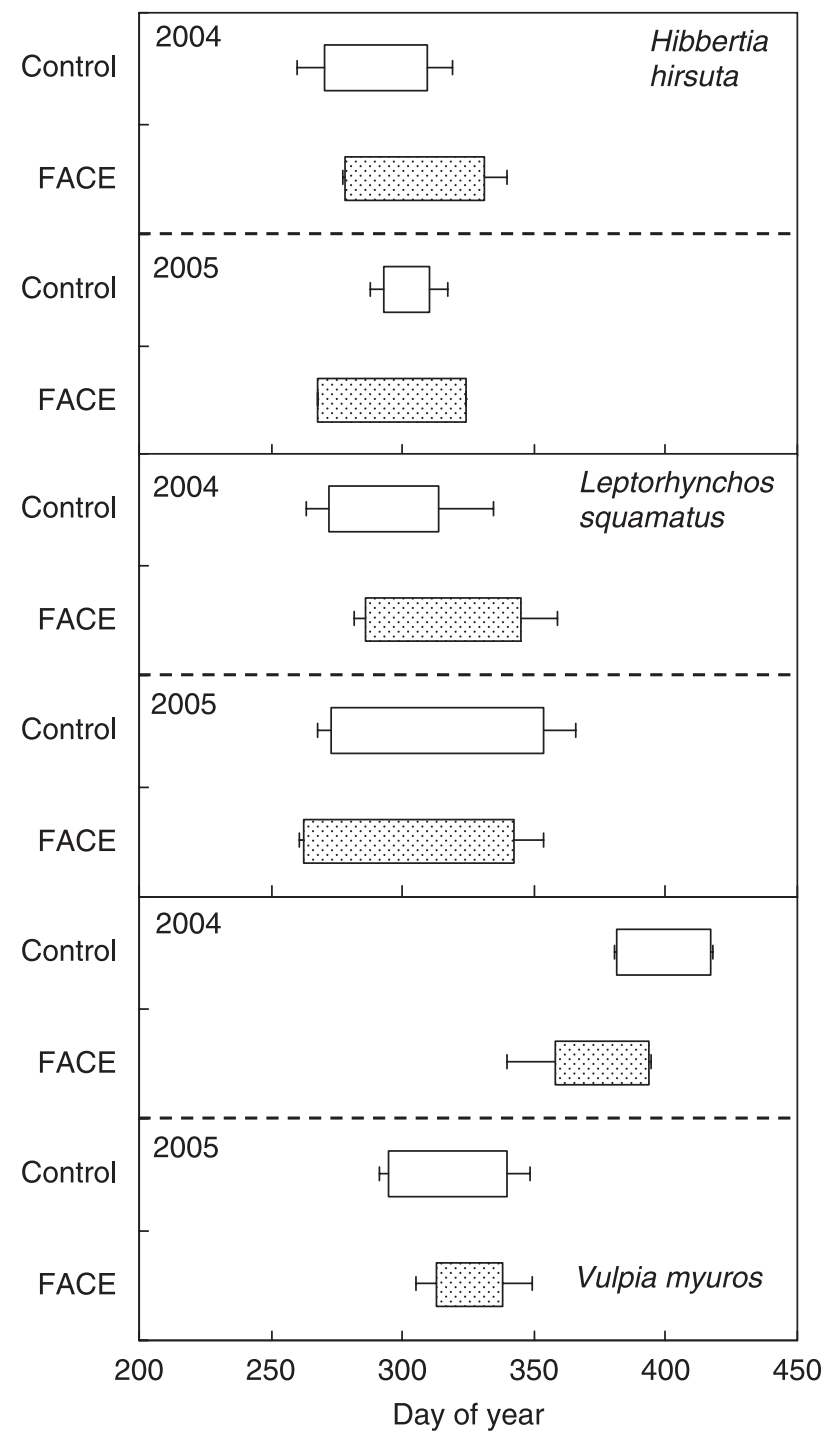

Fig. 2 Flowering times of Hibbertia hirsuta, Leptorhynchos squamatus and Vulpia myuros at control (open bars) and elevated $\mathrm{CO}_{2}$ (free-air $\mathrm{CO}_{2}$ enrichment (FACE); stippled bars) during 2004 and 2005 in the Tasmanian free-air $\mathrm{CO}_{2}$ enrichment experiment (TasFACE). Bars indicate flowering duration from mean flowering commencement to mean flowering conclusion, error bars indicate \pm SE.

In 2004, mean day of first flowering was $316.0 \pm 5.2$ in unwarmed plots and $296.9 \pm 3.7$ in warmed plots, whereas in 2005 , first flowering occurred on day $299.6 \pm 1.8$ in unwarmed plots and 296.6 \pm 2.2 in warmed plots (Fig. 1). Thus, flowering was substantially earlier in warmed plots than in unwarmed plots in 2004 but not in 2005 (Fig. 1). Not surprisingly, the species-level results reflect the overall trends, with warming accelerating the commencement of flowering to a greater degree in 2004 than in 2005 (Table S1). Thus, warming significantly accelerated flowering in 11 out of 19 species in 2004 but only in one out of 21 species in 2005 (Table S1).

\section{Flowering conclusion and flowering duration}

Treatment impacts on flowering conclusion were very similar to those on flowering commencement, with a significant warming $\times$ year interaction and no effect of elevated $\mathrm{CO}_{2}$ (Fig. 1; Table 1). Thus, in 2004, flowering concluded on day $352.5 \pm 5.9$ in unwarmed plots, on day $327.8 \pm 4.3$ in warmed plots compared with the situation in 2005, in which flowering concluded on day $343.9 \pm 2.4$ in unwarmed plots and on day $338.8 \pm 2.7$ in warmed plots (Fig. 1). Given the similar effect of warming on flowering commencement and cessation, there was no overall effect of warming on flowering duration (Fig. 1; Table 1 ) or any warming $\times$ year interaction (Fig. 1; Table 1). There was, however, a significant effect of year, with plants flowering for an average of $33.9 \pm 2.7 \mathrm{~d}$ in 2004 and $44.2 \pm 1.8 \mathrm{~d}$ in 2005 (Fig. 1; Table 1). As with flowering commencement, $\mathrm{CO}_{2}$ concentration did not affect the overall timing of flowering completion or the overall flowering duration (Fig. 1; Table 1).

At the species level, elevated $\mathrm{CO}_{2}$ did not significantly alter flowering conclusion date in any species in either year but it did significantly affect flowering duration of two species. In 2005, the only year in which the species flowered, elevated $\mathrm{CO}_{2}$ significantly increased flowering duration of E. scaber from $8.6 \pm 2.7 \mathrm{~d}$ to $36.8 \pm 5.7 \mathrm{~d}(P<0.003)$. Similarly, elevated $\mathrm{CO}_{2}$ increased flowering duration of $H$. hirsuta in 2004 from $38.7 \pm 10.2 \mathrm{~d}$ to $53.0 \pm 9.0 \mathrm{~d}(P<0.17$; Fig. 2$)$ and in 2005 from $17.5 \pm 7.3 \mathrm{~d}$ to $56.0 \pm 0.0 \mathrm{~d}(P<0.01$; Fig. 2$)$.

\section{Interannual variation in climate}

There was significantly greater rainfall during winter in 2004 than there was in 2005 at the study site (Fig. 3). By contrast, 2005 was substantially warmer in winter than was 2004, particularly during July and August (Fig. 3). Since spring flowering date is often strongly correlated with a thermal sum, such as degree-days, we calculated the number of degree-days from 1 July until the average commencement of flowering in both warmed and unwarmed plots for 2004 and 2005. In 2004, average first flowering occurred at a thermal sum of 1143 degree-days in unwarmed plots compared with 1142 degree-days in warmed plots. By contrast, in 2005 first flowering occurred at a thermal sum of 1153 degree-days in unwarmed plots and at 1326 degree-days in warmed plots. Thus, the warming influence on flowering time in 2004 was very tightly linked with treatment-induced effects on the thermal sum, but this was not the case in 2005, in which flowering occurred at a substantially higher thermal sum in warmed than in unwarmed plots.

\section{Discussion}

In a recent review, Springer \& Ward (2007) assessed the impacts of elevated $\mathrm{CO}_{2}$ on flowering times of both wild and 
(a)

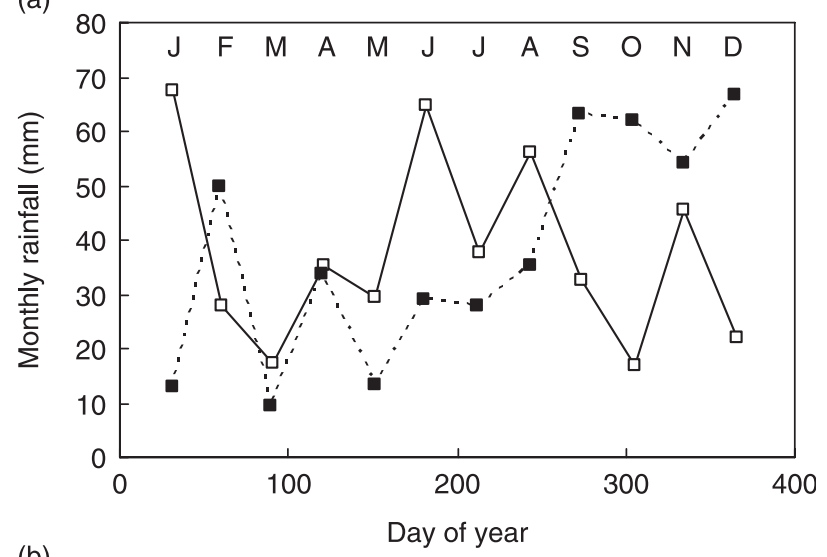

(b)

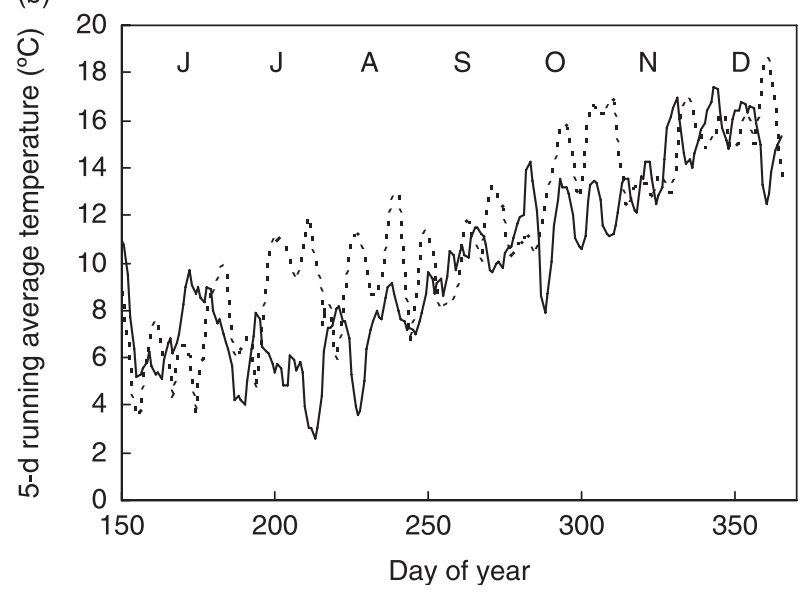

Fig. 3 Monthly rainfall (a) and 5-d running average temperature (b) at the Tasmanian free-air $\mathrm{CO}_{2}$ enrichment experiment (TasFACE) site during 2004 (open squares, solid lines) and 2005 (closed squares, dashed lines). Letters at the top of each graph indicate month.

crop species, showing that while elevated $\mathrm{CO}_{2}$ tended to accelerate flowering of crop species, the responses of wild species were remarkably evenly distributed, with similar proportions of species responding positively, negatively or not at all to elevated $\mathrm{CO}_{2}$. As well as this variation among species, substantial variation within species in the responsiveness of flowering time to elevated $\mathrm{CO}_{2}$ has been demonstrated, both among and within individual studies (Springer \& Ward, 2007). One problem with comparing responses of different species to experimental manipulation is variation among experiments in growth conditions such as nutrient and water availability, light levels, etc., thereby limiting the utility of meta-analyses and similar comparisons of multiple experiments (Körner, 2006). Therefore, experiments such as the TasFACE experiment and other similar experiments (Cleland et al., 2006; Sherry et al., 2007) are extremely useful in that a large number of species are exposed to simulated future conditions at the same time in the same place. Thus, experiments such as this allow valid analyses of the impacts of environmental manipulation on various species.
The results presented here show that while flowering time was very sensitive to experimental warming in at least $1 \mathrm{yr}$, it was remarkably unaffected by $\left[\mathrm{CO}_{2}\right]$ in this southern temperate grassland. Importantly, we found no evidence for any interaction between warming and elevated $\mathrm{CO}_{2}$ on flowering time. Since elevated $\mathrm{CO}_{2}$ can cause substantial changes in plant productivity (Navas et al., 1995), water use (Jackson et al., 1994) and biomass allocation (Cipollini et al., 1993; Dippery et al., 1995; Cotrufo \& Gorissen, 1997), it seems reasonable to expect some influence on reproductive output. Meta-analyses have indicated that elevated $\mathrm{CO}_{2}$ tends to increase total flower and seed production, although the response is strongly dependent upon species (Jablonski et al., 2002). It is possible, therefore, that stimulation of carbon assimilation by elevated $\mathrm{CO}_{2}$ leads to an alteration of flowering time (Springer \& Ward, 2007). However, a survey of published work indicates that there is no general or average response of flowering phenology to elevated $\mathrm{CO}_{2}$ (Springer \& Ward, 2007). As discussed by Springer \& Ward (2007), the mechanisms whereby $\left[\mathrm{CO}_{2}\right]$ affects flowering phenology are poorly understood and seem to vary substantially both among and within species. The lack of response of flowering time to elevated $\mathrm{CO}_{2}$ seen here, and the lack of any $\mathrm{CO}_{2} \times$ warming interaction, indicates that elevated $\mathrm{CO}_{2}$ is unlikely to substantially alter flowering times in southern temperate grasslands in the near future. The TasFACE site is nutrient-poor and flower and seed production of these species are largely unresponsive to $\left[\mathrm{CO}_{2}\right]$ (Hovenden et al., 2007). Therefore, it is possible that nutrient limitations restrict the species' ability to take advantage of the elevated $\mathrm{CO}_{2}$, thus preventing any elevated $\mathrm{CO}_{2}$-induced alterations of flowering phenology or reproductive output (Körner, 2003; Körner, 2006). The few species that were responsive to elevated $\mathrm{CO}_{2}$ treatment did not show a consistent response across the $2 \mathrm{yr}$, indicating that either the responses were related to other factors or that the impact of elevated $\mathrm{CO}_{2}$ on phenology in these species varies from year to year. It is interesting that the two species in which elevated $\mathrm{CO}_{2}$ affected flowering phenology in both years, namely $L$. squamatus and $V$. myuros, are very early- and late-flowering species, respectively. Indeed, L. squamatus is the earliest flowering of all the forbs in the experiment. Whether flowering time has an influence on the sensitivity of flowering phenology to $\mathrm{CO}_{2}$ concentration, as appears to be the case with warming in some communities (Sherry et al., 2007), is currently unknown. As elevated $\mathrm{CO}_{2}$ reduces stomatal conductance, FACE treatment can increase leaf temperature (Long et al., 2004) and this might explain why V. myuros plants flowered earlier in elevated $\mathrm{CO}_{2}$ plots in 2004, the wetter, cooler year, but this does not explain the retardation of flowering in the co-occurring L. squamatus; neither does it explain why warming did not alter the flowering time of either species in either year. Clearly, more work is needed to elucidate the mechanisms whereby $\left[\mathrm{CO}_{2}\right]$ influences flowering time. 
The large difference observed here in average flowering response to warming between years might have been due to differences in rainfall and hence water availability between the $2 \mathrm{yr}$ (Fig. 3). In 2004, the mechanism responsible for the warming-induced acceleration of flowering was likely to be an increase in developmental rates that were limited by sub-optimal ambient temperatures. This is supported by the very close agreement of the thermal sum at mean flowering time in both warmed and unwarmed plots. In 2005, however, warming did not have a similar effect, such that mean flowering occurred at almost exactly the same time in warmed and unwarmed plots, despite differences in their thermal sum. Since there was substantially less winter rainfall in 2005 than in 2004, it would appear that accelerating reproductive developmental rates did not lead to earlier flowering since flowering was probably constrained by water availability, as has been demonstrated previously (Brando et al., 2006; Brearley et al., 2007). Close analysis of the mean flowering times over the $2 \mathrm{yr}$, however, suggests an alternative hypothesis. Mean first flowering in warmed plots occurred on precisely the same day in both years (day $296.9 \pm 3.7$ in 2004 and on day $296.6 \pm 2.2$ in 2005) but in unwarmed plots mean day of first flowering was substantially earlier in 2005 than it was in 2004 (day $316.0 \pm 5.2$ in 2004 and day $299.6 \pm 1.8$ in 2005). This might be related to the warmer ambient temperatures in 2005 (Fig. 3), as flowering of unwarmed plants occurred at a similar thermal sum in both years (1143 degree-days in 2004, 1153 degree-days in 2005). It is possible that beyond a certain point, additional warming cannot accelerate developmental rates, either because optimal developmental temperature has already been reached or because flower production is limited by other factors, such as day length (Rivera $\&$ Borchert, 2001; Keller \& Körner, 2003; Crepinsek et al., 2006). This indicates that warming will cause a finite acceleration in flowering time, to a point where flower induction is limited by factors other than temperature, particularly in areas prone to strongly seasonal rainfall. If this is true, then it is likely that the rate of change of phenological events will reduce as the globe warms.

Direct observations of trends in plant phenology have shown that, on average, 'spring' has been advancing by between 2.3 (Parmesan \& Yohe, 2003) and 5.1 (Root et al., 2003) days per decade during the twentieth century. Similarly, flowering of 385 British plants was $4.5 \mathrm{~d}$ earlier in the 1990s than in the previous four decades (Fitter \& Fitter, 2002), representing a shift in spring flowering corresponding to 4.3-6.0 d advancement per degree of warming. Similar figures have been produced from various observational studies (Menzel, 2003; Menzel et al., 2006; Estrella et al., 2007). Most previous experimental work has shown an acceleration of flowering that is somewhat less than these direct observations. For example, experimental warming of $4.2^{\circ} \mathrm{C}$ in an American tallgrass prairie accelerated mean flowering by $7.6 \mathrm{~d}$, corresponding to $1.8 \mathrm{~d}$ advancement per degree, which is similar to the $1.3-3.3 \mathrm{~d}$ per degree reported for a Californian annual grassland (Cleland et al., 2006). Chambered warming treatments in a range of arctic sites produced a mean acceleration of flowering of 1.7-5.0 d per degree, depending upon year (Arft et al., 1999). Our results show a mean acceleration of flowering of $11.0 \mathrm{~d}$ per degree of warming (overall mean using all species in both years), which is a larger response than most previous reports. Unfortunately, there is very little published flowering phenology data available for Australian species and none from Australian grasslands. In a $23 \mathrm{yr}$ study of four co-occurring Eucalyptus trees from southeastern Australia, it was found that flowering times had not changed measurably in two species, flowering of one species had advanced by $33.0 \mathrm{~d}$ per degree of warming and flowering of one species had been delayed by $21.1 \mathrm{~d}$ per degree of warming (Keatley et al., 2002). It is unclear why the acceleration of flowering was greater in the TasFACE experiment than in similar warming experiments using infrared heaters, but it is possible that timing of productivity plays some role. The experimental site is prone to severe and prolonged summer drought and thus has highest productivity during the cool months when warming might be expected to play a greater role. The winter months are also reasonably mild such that plants may be metabolically active in all winter months, particularly when warmed. It is possible therefore that global warming will have a pronounced effect on spring flowering in this community.

Our results indicate that while mean date of first flowering is very sensitive to experimental warming in some years, the duration of flowering is not. We found no significant treatment effects on mean flowering duration indicating that warming merely shifted flowering in 2004, rather than extending it. This differs with results from subalpine meadows in which earlier flowering led to longer flowering duration (Dunne et al., 2003). It is likely that flowering responses to warming will differ between different climatic regions. In the American tallgrass prairie, experimental warming significantly reduced flowering duration in some species but increased it in others (Sherry et al., 2007), indicating that the response of flowering duration to warming is species-specific.

Since flowering is such an important event in the lifecycle of most flowering plant species, alterations of flowering time by global changes are likely to have important implications for ecological interactions such as pollination, competition for pollinators and seed dispersal times. Changes in these interactions are likely to produce strong selective pressures that act on both the plant species themselves and on other organisms that rely on these plants (Sherry et al., 2007). Ultimately, such changes may affect ecosystem productivity and carbon sequestration ability (Springer \& Ward, 2007). Springer \& Ward (2007) stressed the need for work examining the developmental responses of plants to environmental manipulation in natural settings, particularly to multiple experimental factors. Here we have presented results from a comparatively large number of co-occurring species, all growing in a natural setting with natural climatic variation and limiting resources such as 
nutrients. Our results indicate that in this ecosystem flowering time is sensitive to both warming and interannual variation in climate but is insensitive to elevated $\mathrm{CO}_{2}$. Therefore, the lack of response to manipulation of $\left[\mathrm{CO}_{2}\right]$ does not arise from the flowering times of these species being unresponsive in general, rather being unresponsive to $\left[\mathrm{CO}_{2}\right]$ specifically. Thus, in this ecosystem, at least, the rising atmospheric concentration of $\mathrm{CO}_{2}$ appears unlikely to either ameliorate or accentuate the impacts of global warming on flowering phenology. Just why elevated $\mathrm{CO}_{2}$ fails to elicit any response in flowering time of the vast majority of species in this ecosystem is an area requiring further investigation.

\section{Acknowledgements}

We thank the Australian Federal Department of Defence for access to the Pontville Small Arms Range Complex. This project was supported by the Australian Research Council Discovery Projects scheme.

\section{References}

Ahas R, Aasa A, Menzel A, Fedotova VG, Scheifinger H. 2002. Changes in European spring phenology. International Journal of Climatology 22: $1727-1738$

Arft AM, Walker MD, Gurevitch J, Alatalo JM, Bret-Harte MS, Dale M, Diemer M, Gugerli F, Henry GHR, Jones MH et al. 1999. Responses of tundra plants to experimental warming: Meta-analysis of the international tundra experiment. Ecological Monographs 69: 491-511.

Badeck FW, Bondeau A, Bottcher K, Doktor D, Lucht W, Schaber J, Sitch S. 2004. Responses of spring phenology to climate change. New Phytologist 162: 295-309.

Beaubien EG, Hall-Beyer M. 2003. Plant phenology in western Canada: trends and links to the view from space. Ecological Monitoring and Assessment 88: 419-429.

Brando P, Ray D, Nepstad D, Cardinot G, Curran LM, Oliveira R. 2006. Effects of partial throughfall exclusion on the phenology of Coussarea racemosa (Rubiaceae) in an east-central Amazon rainforest. Oecologia 150: 181-189.

Brearley FQ, Proctor J, Suriantata, Nagy L, Dalrymple G, Voysey BC. 2007. Reproductive phenology over a 10 -yr period in a lowland evergreen rain forest of central borneo. Journal of Ecology 95: 828-839.

Buchanan AM. 1999. A census of the vascular plants of Tasmania. Hobart, Australia: Tasmanian Herbarium.

Cipollini ML, Drake BG, Whigham D. 1993. Effects of elevated $\mathrm{CO}_{2}$ on growth and carbon/nutrient balance in the deciduous woody shrub Lindera benzoin (L.) blume (Lauraceae). Oecologia 96: 339-346.

Cleland EE, Chiariello NR, Loarie SR, Mooney HA, Field CB. 2006. Diverse responses of phenology to global changes in a grassland ecosystem. Proceedings of the National Academy of Sciences, USA 103: 13740-13744.

Cleland EE, Chuine I, Menzel A, Mooney HA, Schwartz MD. 2007. Shifting plant phenology in response to global change. Trends in Ecology \& Evolution 22: 357-365.

Cotrufo MF, Gorissen A. 1997. Elevated $\mathrm{CO}_{2}$ enhances below-ground $\mathrm{C}$ allocation in three perennial grass species at different levels of $\mathrm{N}$ availability. New Phytologist 137: 421-431.

Crepinsek Z, Kajfez-Bogataj L, Bergant K. 2006. Modelling of weather variability effect on fitophenology. Ecological Modelling 194: 256-265.

De Valpine P, Harte J. 2001. Plant responses to experimental warming in a montane meadow. Ecology 82: 637-648.
Dippery JK, Tissue DT, Thomas RB, Strain BR. 1995. Effects of low and elevated $\mathrm{CO}_{2}$ on $\mathrm{C}_{3}$ and $\mathrm{C}_{4}$ annuals I. Growth and biomass allocation. Oecologica 101: 13-20.

Dose V, Menzel A. 2006. Bayesian correlation between temperature and blossom onset data. Global Change Biology 12: 1451-1459.

Dunne JA, Harte J, Taylor KJ. 2003. Subalpine meadow flowering phenology responses to climate change: Integrating experimental and gradient approaches. Ecological Monographs 73: 69-86.

Estrella N, Menzel A, Kramer U, Behrendt H. 2006. Integration of flowering dates in phenology and pollen counts in aerobiology: analysis of their spatial and temporal coherence in Germany (1992-1999). International Journal of Biometeorology 51: 49-59.

Estrella N, Sparks TH, Menzel A. 2007. Trends and temperature response in the phenology of crops in Germany. Global Change Biology 13: $1737-1747$.

Fitter AH, Fitter RSR. 2002. Rapid changes in flowering time in British plants. Science 296: 1689-1691.

Guak S, Olsyzk DM, Fuchigami LH, Tingey DT. 1998. Effects of elevated $\mathrm{CO}_{2}$ and temperature on cold hardiness and spring bud burst and growth in Douglas-fir (Pseudotsuga menziesii). Tree Physiology 18: 671-679.

Hendrey GR, Ellsworth DS, Lewin KF, Nagy J. 1999. A free-air enrichment system for exposing tall forest vegetation to elevated atmospheric $\mathrm{CO}_{2}$. Global Change Biology 5: 293-309.

Hendrey GR, Lewin KF, Nagy J. 1993. Free air carbon dioxide enrichment: Development, progress, results. Vegetatio 104/105: 17-31.

Hovenden MJ, Miglietta F, Zaldei A, Vander Schoor JK, Wills KE, Newton PCD. 2006. The TasFACE climate change impacts experiment: design and performance of combined elevated $\mathrm{CO}_{2}$ and temperature enhancement in a native Tasmanian grassland. Australian Journal of Botany 54: $1-10$.

Hovenden MJ, Wills KE, Vander Schoor JK, Chaplin RE, Williams AL, Nolan MJ, Newton PCD. 2007. Flowering, seed production and seed mass in a species rich temperate grassland exposed to FACE and warming. Australian Journal of Botany 55: 780-794.

Jablonski L, Wang X, Curtis P. 2002. Plant reproduction under elevated $\mathrm{CO}_{2}$ conditions: a meta-analysis of reports on 79 crop and wild species. New Phytologist 156: 9-26.

Jackson RB, Sala OE, Field CB, Mooney HA. 1994. $\mathrm{CO}_{2}$ alters water use, carbon gain, and yield for the dominant species in a natural grassland. Oecologia 98: 257-262.

Keatley MR, Fletcher TD, Hudson IL, Ades PK. 2002. Phenological studies in Australia: potential application in historical and future climate analysis. International Journal of Climatology 22: 1769-1780.

Keeling CD, Chin JFS, Whorf TP. 1996. Increased activity of northern vegetation inferred from atmospheric $\mathrm{CO}_{2}$ measurements. Nature 382: $146-149$

Keller F, Körner C. 2003. The role of photoperiodism in alpine plant development. Arctic Antarctic and Alpine Research 35: 361368.

Körner C. 2003. Nutrients and sink activity drive plant $\mathrm{CO}_{2}$ responses - caution with literature-based analysis. New Phytologist 159: $537-538$

Körner C. 2006. Plant $\mathrm{CO}_{2}$ responses: an issue of definition, time and resource supply. New Phytologist 172: 393-411.

Long SP, Ainsworth EA, Rogers A, Ort DR. 2004. Rising atmospheric carbon dioxide: plants face the future. Annual Review of Plant Biology 55: 591-628.

Menzel A. 2003. Plant phenological anomalies in Germany and their relation to air temperature and NAO. Climatic Change 57: 243-263.

Menzel A, Sparks TH, Estrella N, Koch E, Aasa A, Aha R, Alm-Kubler K, Bissolli P, Braslavska O, Briede A et al. 2006. European phenological response to climate change matches the warming pattern. Global Change Biology 12: 1969-1976. 
Miglietta F, Peressotti A, Primo Vacari F, Zaldei A, De Angelis P, Scarscia Mugnozza G. 2001. Free air $\mathrm{CO}_{2}$ enrichment (FACE) of a poplar plantation: The POPFACE fumigation system. New Phytologist 150: 465-476.

Myneni RB, Keeling CD, Tucker CJ, Asrar G, Nemani RR. 1997. Increased plant growth in the northern high latitudes from 1981 to 1991. Nature 386: 698-702.

Navas ML, Guillerm JL, Fabreguettes J, Roy J. 1995. The influence of elevated $\mathrm{CO}_{2}$ on community structure, biomass and carbon balance of Mediterranean old-field microcosms. Global Change Biology 1: 325-335.

Norby RJ, Hartz-Rubin JS, Verbrugge MJ. 2003. Phenological responses in maple to experimental atmospheric warming and $\mathrm{CO}_{2}$ enrichment. Global Change Biology 9: 1792-1801.

Osborne CP, Chuine I, Viner D, Woodward FI. 2000. Olive phenology as a sensitive indicator of future climatic warming in the mediterranean. Plant, Cell \& Environment 23: 701-710.

Parmesan C, Yohe G. 2003. A globally coherent fingerprint of climate change impacts across natural systems. Nature 421: 37-42.

Penuelas J, Filella I. 2001. Phenology - responses to a warming world. Science 294: 793-795.

Penuelas J, Filella I, Comas P. 2002. Changed plant and animal life cycles from 1952 to 2000 in the Mediterranean region. Global Change Biology 8: $531-544$.

Penuelas J, Filella I, Zhang XY, Llorens L, Ogaya R, Lloret F, Comas P, Estiarte M, Terradas J. 2004. Complex spatiotemporal phenological shifts as a response to rainfall changes. New Phytologist 161: 837-846.

Price MV, Waser NM. 1998. Effects of experimental warming on plant reproductive phenology in a subalpine meadow. Ecology 79: 1261-1271.

Primack D, Imbres C, Primack RB, Miller-Rushing AJ, Del Tredici P. 2004. Herbarium specimens demonstrate earlier flowering times in response to warming in Boston. American Journal of Botany 91: 1260-1264.

Randerson JT, Field CB, Fung IY, Tans PP. 1999. Increases in early season ecosystem uptake explain recent changes in the seasonal cycle of atmospheric $\mathrm{CO}_{2}$ at high northern latitudes. Geophysical Research Letters 26: $2765-2768$

Reid JB, Hill RS, Brown MJ, Hovenden MJ, eds. 1999. Vegetation of Tasmania. Canberra, Australia: Australian Biological Resources Study.

Rivera G, Borchert R. 2001. Induction of flowering in tropical trees by a 30-min reduction in photoperiod: Evidence from field observations and herbarium specimens. Tree Physiology 21: 201-212.

Root TL, Price JT, Hall KR, Schneider SH, Rosenzweig C, Pounds JA. 2003. Fingerprints of global warming on wild animals and plants. Nature 421: $57-60$.

Saavedra F, Inouye DW, Price MV, Harte J. 2003. Changes in flowering and abundance of Delphinium nuttallianum (Ranunculaceae) in response to a subalpine climate warming experiment. Global Change Biology 9: 885-894.

SAS Institute Inc. 2003. SAS/STAT user's guide, version 9.1. Cary, NC, USA: SAS Publishing.

Scheifinger H, Menzel A, Koch E, Peter C. 2003. Trends of spring time frost events and phenological dates in central Europe. Theoretical and Applied Climatology 74: 41-51.

Schleip C, Menzel A, Estrella N, Dose V. 2006. The use of Bayesian analysis to detect recent changes in phenological events throughout the year Agricultural and Forest Meteorology 141: 179-191.

Sherry RA, Zhou XH, Gu SL, Arnone JA, Schimel DS, Verburg PS, Wallace LL, Luo YQ. 2007. Divergence of reproductive phenology under climate warming. Proceedings of the National Academy of Sciences, USA 104: 198-202.

Sparks TH, Menzel A. 2002. Observed changes in seasons: An overview. International Journal of Climatology 22: 1715-1725.

Springer CJ, Ward JK. 2007. Flowering time and elevated atmospheric $\mathrm{CO}_{2}$. New Phytologist 176: 243-255.

Stefanescu C, Penuelas J, Filella I. 2003. Effects of climatic change on the phenology of butterflies in the northwest Mediterranean basin. Global Change Biology 9: 1494-1506.

Suzuki S, Kudo G. 2000. Responses of alpine shrubs to simulated environmental change during 3 yr in the mid-latitude mountain, northern Japan. Ecography 23: 553-564.

Walther GR. 2004. Plants in a warmer world. Perspectives in Plant Ecology Evolution and Systematics 6: 169-185.

Walther GR, Post E, Convey P, Menzel A, Parmesan C, Beebee TJC, Fromentin JM, Hoegh-Guldberg O, Bairlein F. 2002. Ecological responses to recent climate change. Nature 416: 389-395.

Williams AL, Wills KE, Janes JK, Vander Schoor JK, Newton PCD, Hovenden MJ. 2007. Warming and free air $\mathrm{CO}_{2}$ enrichment alter demographics in four co-occurring grassland species. New Phytologist 176: 365-374.

Zhou LM, Tucker CJ, Kaufmann RK, Slayback D, Shabanov NV, Myneni RB. 2001. Variations in northern vegetation activity inferred from satellite data of vegetation index during 1981 to 1999 . Journal of Geophysical Research-Atmospheres 106: 20069-20083.

\section{Supplementary Material}

The following supplementary material is available for this article online:

Table S1 The impact of elevated $\mathrm{CO}_{2}$ and warming as main effects on flowering commencement (days) of species in the TasFACE experiment during 2004 and 2005

This material is available as part of the online article from: http://www.blackwell-synergy.com/doi/abs/10.1111/ j.1469-8137.2008.02419.x

(This link will take you to the article abstract).

Please note: Blackwell Publishing are not responsible for the content or functionality of any supplementary materials supplied by the authors. Any queries (other than missing material) should be directed to the journal at New Phytologist Central Office. 